\title{
ENVIRONMENTAL IMPACT ANALYSIS OF HEAVY METAL CONCENTRATIONS IN WASTE MATERIALS USED IN ROAD CONSTRUCTION
}

\author{
Scientiffic paper / Znanstveni rad
}

\author{
Ivanka Netinger Grubeša \\ Josip Juraj Strossmayer University of Osijek, Faculty of Civil Engineering Osijek, Associate Professor \\ Corresponding author: nivanka@gfos.hr \\ Ivana Barišić \\ Josip Juraj Strossmayer University of Osijek, Faculty of Civil Engineering Osijek, Assistant Professor
}

\begin{abstract}
Use of solid waste in place of conventional materials in civil engineering structures preserves natural resources and energy and avoids expensive and/or potentially harmful waste disposal. Many studies are investigating the application of waste materials in civil engineering structures. However, in an effort to find out new areas of waste materials utilization, the environmental impact of the installation of such materials in building structures often remains neglected. This study focused on the environmental aspect of the application of currently investigated waste materials in Croatia with an emphasis on heavy metal content. Heavy metal concentration in steel slag, river sediment, and biomass ash was measured, and the possibility of their use in road construction in accordance with currently valid legislation was assessed.
\end{abstract}

Keywords: heavy metal, steel slag, river sediment, biomass ash, road construction

\section{ANALIZA EKOLOŠKOG UTJECAJA SADRŽAJA TEŠKIH METALA U OTPADNIM MATERIJALIMA PRIMIJENJENIM U CESTOGRADNJI}

\begin{abstract}
Sažetak: Uporaba krutog otpada umjesto konvencionalnih materijala u građevinarstvu pridonosi očuvanju prirodnih izvora i energije, čime je ujedno izbjegnuto skupo te potencijalno opasno odlaganje takvog otpada. Mnogo je istraživanja na temu primjene otpadnih materijala u graditeljstvu. Međutim, u nastojanju da se pronađu nova područja primjene otpadnih materijala, utjecaj ugradnje takvih materijala u građevinske konstrukcije na okoliš često puta ostaje zanemaren. Ovaj rad bavi se ekološkim aspektom primjene trenutačno istraživanih otpadnih materijala u Hrvatskoj, s naglaskom na sadržaj teških metala. Određeni su sadržaji teških metala u čeličanskoj zguri, talogu iz riječnog nanosa i pepelu biomase te procijenjena mogućnost njihove primjene u cestogradnji s obzirom na trenutačno važeće zakonodavstvo.
\end{abstract}

Ključne riječi: teški metali, čeličanska zgura, riječni sediment, pepeo biomase, cestogradnja 


\section{INTRODUCTION}

Civil engineering is an activity that essentially relies on natural resource exploitation. This is particularly true of road construction, which is one branch of civil engineering wherein rehabilitation and maintenance of newly built and existing roads consumes large amounts of natural resources such as gravel, stone, and sand. For sustainable development within road construction, improved environmental protection can be achieved by more efficient waste material disposal and its usage in the pavement structure. In recent years, scientific researchers have focused on finding new applications for waste material in road structures, mainly by material characterization and determination of materials' physical and mechanical characteristics. Before deciding on possible waste material uses in any branch of civil engineering, it is also necessary to consider potential adverse effects on the environment, as environmental acceptability is a fundamental principle for sustainable recycling. This is particularly important for road structure materials because pavement and embankment structures are in direct contact with the surrounding soil and potential pollution can very easily reach groundwater.

Prior to this study, the authors have investigated the possibility of steel slag and river sediment use in road structures and more recently, have also focused on the application of biomass ash. Steel slag, a by-product of steel production, is produced during the separation of molten steel from impurities in steel production furnaces. These impurities consist of carbon monoxide, silica, manganese, phosphorus, and some iron in the form of liquid oxides [1]. Combined with lime and dolomite-lime, these impurities create steel slag. Because there are three different procedures in steel production, depending on the type of furnace, the slags are often referred to by the type of furnace used in their production (BOF - Basic Oxygen Furnace, EAF - Electric Arc Furnace, SM - Siemens Martin Furnace). On the Croatian territory, there are two slag landfills located near the cities of Sisak and Split, both of which contain air-cooled, electric arc slag deposits from steel production. Detailed characteristics of these materials are presented in the referenced studies [2-4].

Riverbed sedimentation is a hydromorphological process caused by natural features of a watercourse (slope, geological characteristics, sediment grain size, etc.) or induced by anthropogenic activities (dams, barriers). Sedimentation affects a river's form by changing its cross sections at locations where sedimentation is a dominant process. Deposited sediments should be monitored and excessive amounts dredged out to maintain normal river activities, maintain port mobility, and satisfy minimum depth requirements. This is particularly the case in basin river ports, where the flow velocities are very low. It is estimated that several hundred million tons of dredged sediments are generated annually around the world [5]. Main river ports are usually located to optimize access to land and navigable water, for commercial demand and for shelter from wind and waves. They are normally located on a part of the river where water velocities are sufficient to prevent serious sedimentation problems; however, regular maintenance activities (dredging) are still necessary. On the other hand, small river ports, usually organized for special purposes such as winter ports, are located on river branches or main streams protected by groins or piers. The flow velocities in these locations are much lower, resulting in a more intensive sedimentation process and a need for more intensive maintenance. Two such winter ports are located on the Drava River in the city of Osijek (Figure 1) and on the Danube River in the city of Vukovar (Figure 2).

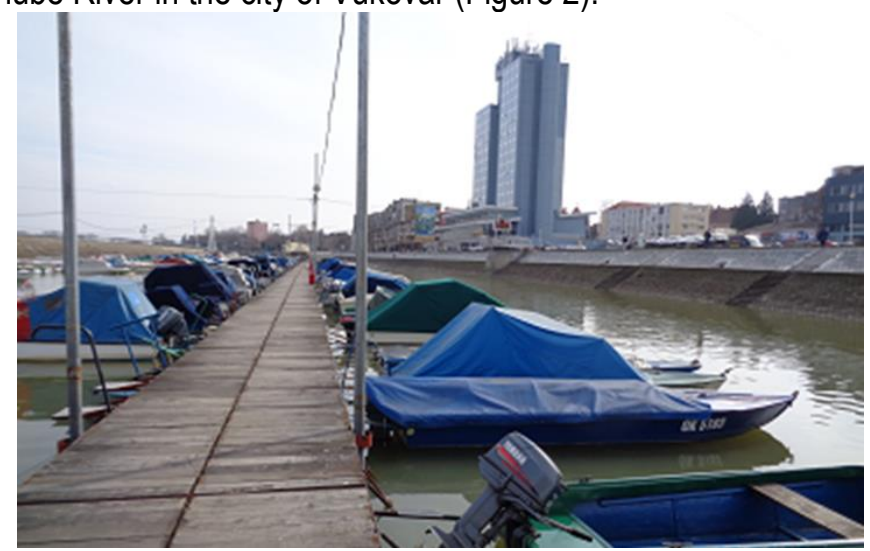

Figure 1 Winter port, special purpose port, Drava River, Osijek

Netinger Grubeša, I, Barišić, I 


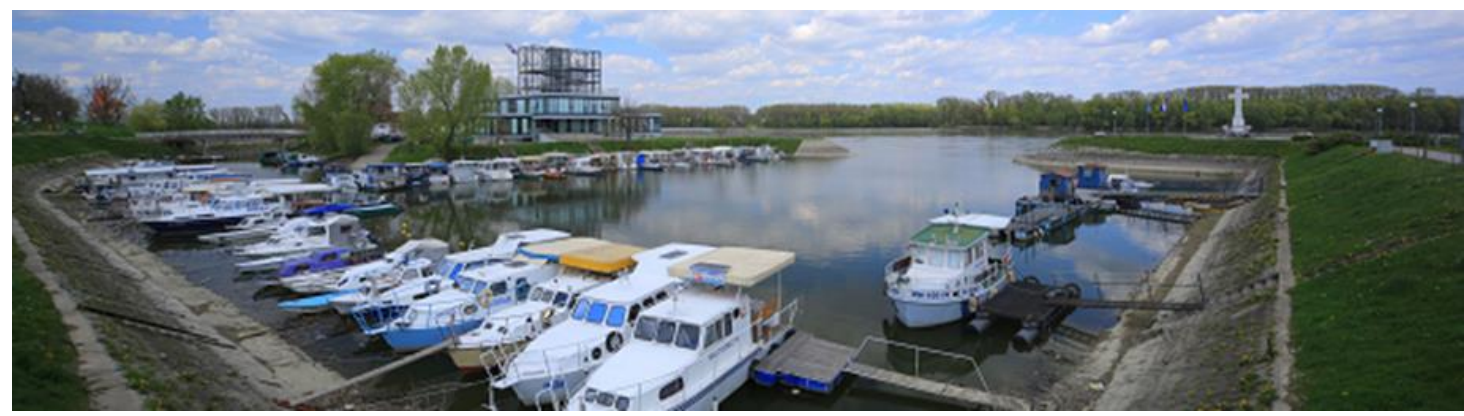

Figure 2 Winter port, special purpose port, Danube River, Vukovar

Generally, dredged sediments are very soft soils with notably low mechanical strength, extremely high moisture content, and may be contaminated with organic and inorganic pollutants or toxic chemicals, particularly when they are derived from a toxic industrial area [6]. In such state, this material cannot be used as a geomaterial for civil engineering purposes. Conventional disposal solutions for dredged sediments, such as ocean disposal and depositing into landfills, are gradually becoming restricted in many countries in order to protect the environment. The beneficial uses of dredged sediments are becoming increasingly important in terms of environmental protection and sustainable development. Potential utilization of river port sediment extracted from the Danube, Drava, and Sava Rivers was analyzed during project CLEAR BASIN: Research of River-Port Sediment and its Potential use in Civil Engineering financed by the Danube Region Project Fund. Within this project, laboratory research was performed in order to define basic characteristics of port sediment for possible application recommendations.

Biomass is relatively cheap, renewable, and plentifully supplied all over the world. It can originate from woody crops and vegetable plants or may be generated from agricultural industry by-products. Through Directive 2009/28/EC, promoting the use of energy from renewable sources [7], the EU has set a mandatory target of generating $20 \%$ of energy from renewable sources by 2020. Today, this is a primary reason for increased use of biomass as a substitute for commonly used fuels in EU industrial applications. Using biomass as an energy source can save energy, conserve non-renewable resources, and protect the environment. Further, biomass ash resulting from biomass combustion is a waste that should find application. To date, biomass ash has been used as a raw material for fertilizer, as a building material, as a component in the manufacture of building materials, as well as a fuel in industry [8]. Biomass ash analyzed in this study was generated during the combustion of sunflower seeds in an oil factory located near Osijek and so far has not found an area of application.

When waste materials are used in a road structure (pavement or embankment), there is the potential of toxic elements influencing the environment through road runoff, groundwater, and/or soil contamination. Although heavy metals occur naturally in soil and groundwater, their concentrations are rarely at toxic levels. On the other hand, while runoff water can be contaminated by heavy metals from the abrasion of tires (zinc, cadmium), brakes (copper), and other elements in the road and car park area (zinc, lead, etc.) [9], heavy metals contamination of soil and underground water is affected by materials used within the road structure.

Heavy metals with the highest potential for hazardous environmental impact if used in road engineering primarily involve the following elements: $\mathrm{Fe}, \mathrm{Mn}, \mathrm{Ti}, \mathrm{Al}, \mathrm{Ca}, \mathrm{Mg}$, and $\mathrm{Cr}[10,11]$. Because these heavy metals represent the highest concern regarding possible health effects or bioaccumulation, many studies are currently investigating $\mathrm{Cr}$ and $\mathrm{V}$. The potential toxicity and mobility of possible harmful elements (such as $\mathrm{Cr}$ and $\mathrm{V}$ ) depends on, among other factors, their chemical form or speciation (oxidation state, molecular geometry, and coordination environment) [5]. In the case of $\mathrm{Cr}$, special attention should be paid to $\mathrm{Cr}(\mathrm{VI})$ because this form of $\mathrm{Cr}$ is carcinogenic. $\mathrm{Cr}(\mathrm{VI})$ and the most toxic chemical form of $\mathrm{V}$, the pentavalent form, are found to be toxic for both plants and animals [4].

According to Croatian regulations [12], which are in accordance with European Directives 2000/60/EC, 2006/118/EC, and 2006/11/EC concerning wastewater treatment, emission limits of some heavy metal pollution in surface water are given in Table 1. 
Table 1 Limit values of heavy metals in industrial waste water discharged to surface waters

\begin{tabular}{cc} 
Element & Maximal limited value $(\mathrm{mg} / \mathrm{L})$ \\
\hline $\mathrm{Al}$ & 3 \\
$\mathrm{Cr}-$ total & 0,5 \\
$\mathrm{Cr}(\mathrm{Vl})$ & 0,1 \\
$\mathrm{Fe}$ & 2 \\
$\mathrm{~V}$ & 0,05 \\
$\mathrm{Cu}$ & 0,5 \\
$\mathrm{Zn}$ & 2 \\
$\mathrm{Mn}$ & 2 \\
$\mathrm{Hg}$ & 0,01 \\
$\mathrm{Fe}$ & 2
\end{tabular}

According to Croatian regulation, the only guideline for heavy metal concentration in soil is defined in the Ordinance on the protection of agricultural land against pollution caused by harmful substances [13], which defines limit values of heavy metal concentration in agricultural soil based on material texture (Table 2).

Table 2 Maximal values of heavy metal concentration in agricultural terrain $(\mathrm{mg} / \mathrm{kg})$

\begin{tabular}{cccccccc} 
Texture & $\mathbf{C d}$ & $\mathbf{P b}$ & $\mathbf{N i}$ & $\mathrm{Hg}$ & $\mathbf{Z n}$ & $\mathbf{C u}$ & $\mathrm{Cr}$ \\
\hline Sandy soil & $0,0-0,5$ & $0-50$ & $0-30$ & $0,0-0,5$ & $0-60$ & $0-60$ & $0-40$ \\
Silty loam soil & $0,5-1,0$ & $50-100$ & $30-50$ & $0,5-1,0$ & $60-150$ & $60-90$ & $40-80$ \\
Loam soil & $1,0-2,0$ & $100-150$ & $50-75$ & $1,0-1,5$ & $150-200$ & $90-120$ & $80-120$
\end{tabular}

Finnish legislation [14], for example, sets lower and higher concentration levels by each hazardous element to identify the soil contamination by land use. Higher concentration levels are defined by major land uses, i.e., for industrial or transport sites, while a lower concentration level is set for all other land uses (Table 3). According to the same resource, if the lower value of $\mathrm{Pb}$ concentration is exceeded (* mark), there is a potential health risk, while for all other elements and values (lower and higher) there is an ecological risk.

\begin{tabular}{cccccccccc}
\multicolumn{8}{c}{ Table 3} & \multicolumn{6}{c}{ Guideline values of heav } \\
Element & As & Co & Cd & Pb & Ni & Hg & Zn & Cu & Cr \\
\hline $\begin{array}{c}\text { Lower } \\
\text { guideline value }\end{array}$ & 50 & 100 & 10 & $200^{*}$ & 100 & 2 & 250 & 150 & 200 \\
$\begin{array}{c}\text { Higher } \\
\text { guideline value }\end{array}$ & 100 & 250 & 20 & 750 & 150 & 5 & 400 & 200 & 300
\end{tabular}

In order to define the potential environmental risk of using waste materials of Croatian origin in road construction, this study analyzed the impact of steel slag, biomass ash, and river port sediment on total heavy metal concentrations.

\section{EXPERIMENTAL PART}

\subsection{METHODS}

Total heavy metal concentration in two Croatian steel slags was determined according to the following ISO standards: 11466 Soil quality - Extraction of trace elements soluble in aqua regia [15] and 11047 Soil quality Determination of cadmium, chromium, cobalt, copper, lead, manganese, nickel and zinc in aqua regia extract of soil - Flame and electrothermal atomic absorption spectrometric methods [16] .To determine the concentration of trace elements $\mathrm{Cd}, \mathrm{Pb}, \mathrm{As}$, and $\mathrm{Ni}$ in biomass ash and sediment, the EN ISO 15586 standard using atomic absorption spectrometry with electrothermal atomization[17] was used. To measure $\mathrm{Hg}$ levels in sediment, the AAS 019 REV standard was used. To determine concentrations of $\mathrm{Mn}, \mathrm{Zn}, \mathrm{Cu}, \mathrm{Co}$, and $\mathrm{Cr}$ in biomass ash and sediment, as well as Fe in sediment, destruction by aqua regia was used [16]. This method provides the fastest, safest, and 
most precise analytical results with an accuracy of more than $5 \%$. Each of the studied waste materials were analyzed for those heavy metals named in Tables 1,2 , and 3 whose presence was recorded in the literature [10, $18,19]$.

In addition, classification of waste material with regard to soil and groundwater protection has traditionally been based on total contaminant concentrations measured in the solids. However, the leaching properties of a material correspond directly to the risk of potential release of harmful substances from the material to groundwater or soil. Therefore, leaching tests must be conducted if a high metal concentration is recorded in the material. Due to the anticipated high metal concentration in samples with a steel slag origin, leaching tests in accordance with EN 12457-2:2002 [20] were also performed.

\subsection{RESULTS}

The concentrations of heavy metal in slag are given in Table 4, in river port sediment in Table 5 and in biomass ash in Table 6. Leaching of heavy metals from slag samples is given in Table 7.

\begin{tabular}{|c|c|c|}
\hline Element & $\begin{array}{c}\text { Slag Sisak } \\
\text { Total content }(\mathrm{mg} / \mathrm{kg})\end{array}$ & $\begin{array}{c}\text { Slag Split } \\
\text { Total content }(\mathrm{mg} / \mathrm{kg})\end{array}$ \\
\hline Al & 7033.33 & 2970.00 \\
\hline $\mathrm{Ca}$ & 106000.00 & 64066.00 \\
\hline Mg & 131200.00 & 38666.00 \\
\hline $\mathrm{Cr}$ & 10563.00 & 7780.00 \\
\hline $\mathrm{Ti}$ & 222.36 & 388.33 \\
\hline $\mathrm{Mn}$ & 1778.00 & 581.00 \\
\hline $\mathrm{Fe}$ & 9230.00 & 7153.33 \\
\hline V-pentoxide & 242.12 & 92.50 \\
\hline
\end{tabular}

Table 5 Heavy metal concentration in river port sediment samples $(\mathrm{mg} / \mathrm{kg})$

\begin{tabular}{ccc} 
Element & $\begin{array}{c}\text { Danube River } \\
\text { Total content }(\mathrm{mg} / \mathrm{kg})\end{array}$ & $\begin{array}{c}\text { Drava River } \\
\text { Total content }(\mathrm{mg} / \mathrm{kg})\end{array}$ \\
\hline $\mathrm{Cd}$ & 0.68 & 2.55 \\
$\mathrm{~Pb}$ & 35.4 & 305.0 \\
$\mathrm{As}$ & 13.5 & 27.2 \\
$\mathrm{Ni}$ & 24.1 & 33.9 \\
$\mathrm{Hg}$ & 0.41 & 0.49 \\
$\mathrm{Fe}$ & 195.7 & 358.7 \\
$\mathrm{Mn}$ & 5.12 & 6.89 \\
$\mathrm{Zn}$ & 1.01 & 5.28 \\
$\mathrm{Cu}$ & 0.22 & 0.52 \\
$\mathrm{Co}$ & 0.09 & 0.14 \\
$\mathrm{Cr}$ & 0.33 & 0.74
\end{tabular}

Table 6 Heavy metal concentration in biomass ash sample $(\mathrm{mg} / \mathrm{kg})$

\begin{tabular}{cc} 
Element & Total content $(\mathrm{mg} / \mathrm{kg})$ \\
\hline $\mathrm{Cd}$ & 5,02 \\
$\mathrm{~Pb}$ & 0,12 \\
$\mathrm{As}$ & $<0,04$ \\
$\mathrm{Ni}$ & 22,1 \\
$\mathrm{Mn}$ & 206 \\
$\mathrm{Zn}$ & 570 \\
$\mathrm{Cu}$ & 242 \\
$\mathrm{Co}$ & 0,32 \\
$\mathrm{Cr}$ & 3,21
\end{tabular}




\begin{tabular}{|c|c|c|}
\hline Component & $\begin{array}{c}\text { Slag Sisak } \\
\text { Leaching (mg/L) }\end{array}$ & $\begin{array}{c}\text { Slag Split } \\
\text { Leaching (mg/L) }\end{array}$ \\
\hline Al & 0.0685 & 0.0792 \\
\hline $\mathrm{Ca}$ & 0.0173 & 0.0526 \\
\hline Mg & 0.061 & 0.0643 \\
\hline $\mathrm{Cr}$ & 0.221 & 0.015 \\
\hline $\mathrm{Ti}$ & not measured & not measured \\
\hline $\mathrm{Mn}$ & not measured & not measured \\
\hline $\mathrm{Fe}$ & 0.071 & 0.0526 \\
\hline V-pentoxide & 0.0189 & 0.0034 \\
\hline
\end{tabular}

\subsection{DISCUSSION}

By analyzing results of the total heavy metals content in two steel slag samples presented in Table 4, higher values of all tested heavy metals were observed compared to the limiting values presented in Tables 2 and 3 , which was expected due to steel slag generation. Although the concentrations of $\mathrm{Cr}, \mathrm{V}$, and $\mathrm{Fe}$ in both slags is very high (Table 4), the leaching values (Table 7) for those elements are within the limits prescribed for surface wastewater discharges by Table 1. Therefore, the steel slag samples in this study are suitable for use in road structures.

As presented in Table 5, heavy metals were recorded within both tested river port sediment samples. Generally, $\mathrm{Fe}$ and $\mathrm{Pb}$ were present in the highest concentrations, while the lowest values were obtained for $\mathrm{Co}$ and $\mathrm{Cu}$. Based on the limit values and results presented in Tables 2 and 5 , respectively, it can be seen that the tested sediment samples from the Drava (Osijek port) and Danube (Vukovar port) Rivers satisfy the requirements for agricultural terrain, except in terms of $\mathrm{Cd}$ and $\mathrm{Pb}$ values. Sediment from the Danube River had lower values of all tested heavy metal concentrations than the Drava River sample. However, the limit values previously presented are very strict as they relate to agricultural terrain. According to the Finnish guideline values presented in Table 3 , the sediment from Drava River presents a potential health risk ( $\mathrm{Pb}$ exceeds lower guideline value). However, all tested samples satisfy higher guideline values for use in industrial and transport areas, for example as subgrade, embankment, or unbound base layers.

As presented in Table 6, heavy metals were recorded within the sample of biomass ash. The concentration of $\mathrm{Cd}$ is above the limits prescribed in Table 2, but within the limits given in Table 3 . However, the concentrations of $\mathrm{Zn}$ and $\mathrm{Cu}$ are above the limits prescribed in both tables (Tables 2 and 3).According to the only available Croatian standard dealing with heavy metal concentration in soil, the biomass ash analyzed in this study may not be used for agricultural purposes. Due to high concentrations of $\mathrm{Zn}$ and $\mathrm{Cu}$, it is recommended to perform a leaching test prior to deciding whether to use this material in road construction.

\section{CONCLUSION}

In order to properly define the potential uses of waste materials in civil engineering, detailed analyses on each material's potential adverse effect on the environment must be conducted, primarily due to the fact that environmental acceptability is a fundamental principle of sustainable recycling. This is particularly important within road structure materials because pavement and embankment structures are in direct contact with the surrounding soil and potential pollution can very easily reach groundwater. For that purpose, this research tested total heavy metal concentrations on three different types of waste materials whose application in civil engineering has been proven at the basic physical-mechanical material properties level. Results of laboratory tests suggest that total content of heavy metals within a material matrix is strongly influenced by material origin. To properly define potential environmental risk of waste material usage in road construction, it is necessary to conduct very detailed analyses on total heavy metals concentrations and on leaching potential of hazardous substances contained within a material matrix. However, heavy metal concentration limits, both total and leached, are insufficiently addressed within current Croatian legislation, and existing ordinances cannot be used when addressing materials for civil engineering purposes. 


\section{References}

[1] User Guidelines for Waste and Byproduct Materials in Pavement Construction, Steel slag, Publication Number: FHWA-RD-97-148, https://www.fhwa.dot.gov/publications/research/infrastructure/structures/97148/ssa1.cfm . Accessed 13 December 2016.

[2] Netinger, I.;Bjegović, D.; Vrhovac, G. 2011: Utilisation of steel slag as an aggregate in concrete, Materials and structures, 44(9), pp. 1565-1575. https://doi.org/10.1617/s11527-011-9719-8

[3] Barišić, I.; Dimter, S.; Rukavina, T. 2014: Strength properties of steel slag stabilized mixes. Composites: Part B. 58. Pp. 386-391. https://doi.org/10.1016/i.compositesb.2013.11.002

[4] Netinger Grubeša I.; Barišić l.; Fučić A.; Bansode S.S. 2016: Characteristics and Uses of Steel Slag in Building Construction; Woodhead Publishing House, Elsevier

[5] Dubois, V., et al. 2009: The use of marine sediments as a pavement base material. Waste Management, 29(2), pp. 774-782. https://doi.org/10.1016/i.wasman.2008.05.004

[6] Xu, Y., et al. 2014: The use of urban river sediments as a primary raw material in the production of highly insulating brick. Ceramics International, 40, pp. 8833-8840. https://doi.org/10.1016/j.ceramint.2014.01.105

[7] Directive 2009/28/EC on the promotion of the use of energy from renewable sources, http://eurlex.europa.eu/legal-content/en/ALL/?uri=CELEX\%3A32009L0028, Accessed 13 December 2016.

[8] Pels, R.J.; S. de Nie, D.; H.A. Kiel, J. 2005: Utilization of ashes from biomass combustion and gasification $14^{\text {th }}$ European Biomass Conference \& Exhibition, Paris, France

[9] Lucke, T.; Dierkes, D. 2015: Addressing the demands of the new German permeable pavement design guidelines and the hydraulic behaviour of a new paving design, Journal of Engineering Science and Technology, Special Issue on ACEE 2015 Conference August, 8, pp. 14-28

[10] Gomes, J.F.P.; Pinto, C.G. 2006: Leaching of heavy metals from steelmaking slags. Revista de Metalurgia. 42(6), pp. 409-416

[11] Barišić, I.; Netinger Grubeša, I.; Hackenberger Kutuzović, B. 2016: Multidisciplinary approach to the environmental impact of steel slag reused in road construction, Road Materials and Pavement Design. https://doi.org/10.1080/14680629.2016.1197143

[12] Ministry of Agriculture, Croatian Government. 2010: Pravilnik o graničnim vrijednostima emisija otpadnih voda. Zagreb, Croatia: Official Gazette 80/13, 43/14, 27/15, 3/16 (in Croatian)

[13] Ministry of Agriculture, Croatian Government. 2014: Pravilnik o zašiti poljoprivrednog zemljišta od onečišćenja. Zagreb, Croatia: Official Gazette 9/14 (in Croatian)

[14] Tóth, G.; Hermann, T.; Da Silva, M.R.; Montanarella, L. 2016: Heavy metals in agricultural soils of the European Union with implications for food safety, Environment International, 88, pp. 299-309. https://doi.org/10.1016/i.envint.2015.12.017

[15] ISO 11466:1995 Soil quality - Extraction of trace elements soluble in aqua regia

[16] ISO 11047:1998 Soil quality - Determination of cadmium, chromium, cobalt, copper, lead, manganese, nickel and zinc in aqua regia extract of soil - Flame and electrothermal atomic absorption spectrometric methods

[17] EN ISO 15586:2008 standard using atomic absorption spectrometry with electrothermal atomization

[18] Haiyang, C.; Ruihui, C.; Yanguo, T.; Jin, W. 2016: Contamination characteristics, ecological risk and source identification of trace metals insediments of the Le' an River (China), Ecotoxicology and Environmental Safety, 125, pp. 85-92, http://dx.doi.org/10.1016/.ecoenv.2015.11.042

[19] Demirbas., A. 2005: Heavy Metal Contents of Fly Ashes from Selected Biomass Samples, Energy Sources, 27(13), pp. 1269-1276, https://doi.org/10.1080/009083190519384

[20] EN 12457-2:2002 Characterisation of waste. Leaching. Compliance test for leaching of granular waste materials and sludges. One stage batch test at a liquid to solid ratio of $10 \mathrm{l} / \mathrm{kg}$ for materials with particle size below $4 \mathrm{~mm}$ (without or with size reduction) 